\title{
Microbiological Environmental Monitoring in Pharmaceutical Facility
}

\author{
Mohammed Seif El-Din Ashour ${ }^{1}$; Moselhy Salah Mansy ${ }^{2}$ and \\ Mostafa Essam Eissa ${ }^{3}$ \\ 1- Faculty of Pharmacy October University, Egypt. \\ 2- Faculty of Pharmacy Boys, Al-Azhar University, Cairo, Egypt. \\ 3-Hikma Pharma pharmaceutical company, Egypt. \\ e-mail: mostafaessameissa@yahoo.com
}

\begin{abstract}
Regular environmental monitoring samples for microbiological quality of different locations in pharmaceutical facility are by far very critical measure in controlling clean area and environment which have direct impact on the microbiological quality of the final pharmaceutical products. Different methods were used to collect samples from different locations. These samples were processed and followed by isolation and identification. The obtained data were analyzed to find microbial distribution in the environment of pharmaceutical facility. Twenty one bacterial and fungal species were isolated from different locations in the pharmaceutical facility. Group of genus Staphylococci contributes to $38.4 \%$ of total positive samples while genus Micrococci contributes to $22.4 \%$ and Gemella morbillorum represents $1.1 \%$. Genus Bacilli represents $35.0 \%$, Candida albicans $1.3 \%$, Klebsiella pneumonia $1.0 \%$ and Stenotrophomonas maltophilia $0.01 \%$. Most microorganisms found among 7 identified genuses were belonging to Staphylococcus, Micrococcus and Bacillus species.
\end{abstract}

Key words: Environmental monitoring, settle plate, reuter centrifugal sampler, miniaturized identification system, contact plate.

\section{INTRODUCTION}

Environmental monitoring describes the microbiological testing undertaken in order to detect changing trends of microbial counts and microflora growth within clean room or controlled environments. The results obtained provide information about the physical construction of the room, the performance of the heating, ventilation, and air-conditioning (HVAC) system, personnel cleanliness, gowning practices, the equipment, and cleaning operations (Sandle, 2006).

The design and construction of clean rooms and controlled environments are covered in Federal Standard 209E. This standard of air cleanliness is defined by the absolute concentration of airborne particles. Methods used for the assignment of air classification of controlled environments and for monitoring of airborne particulates are included. This federal document only applies to airborne particulates within a controlled environment and is not intended to characterize the viable or nonviable nature of the particles (USP, 2001).

Although there is no direct relationship established between the 209E controlled environment classes and microbiological levels, the pharmaceutical industry has been using microbial levels corresponding to these classes for a number of years; and these levels have been those used for evaluation of current GMP compliance (Mashburn and Whitfield, 1967). 
Adequately separating areas of operation is an important part of contamination prevention. To maintain air quality in areas of higher cleanliness, it is important to achieve a proper airflow and a positive pressure differential relative to adjacent less clean areas. Rooms of higher air cleanliness should have a substantial positive pressure differential relative to adjacent rooms of lower air cleanliness. For example, a positive pressure differential of at least 12.5 Pascals should be maintained at the interface between classified and unclassified areas (FDA, 2002).

Clean rooms are normally designed as functional units with specific purposes. A well-designed clean room is constructed with materials that allow for ease of cleaning and sanitizing. Examples of adequate design features include seamless and rounded floor to wall junctions as well as readily accessible corners. Floors, walls, and ceilings are constructed of smooth and hard surfaces that can be easily cleaned (CDER, 2003).

The most likely microflora found in pharmaceutical manufacturing can be hard to come by a definite source. The most commonly occurring microorganisms come from human skin (either commensurable or transient) are Gram positive microorganisms and common environmental fungi which include the following:

Staphylococcus aureus, Staphylococcus epidermidis, Staphylococcus capitis, Staphylococcus hominis, Micrococcus species, Bacillus species and Candida species. Whereas those associated with eyes, ears and mucus include Gramnegative microorganisms, which can arise on rare occasions directly from the operator and include the following: Pseudeomonas aeruginosa, and Escherichia coli (Jiminez, 2004).

Strains of Staphylococcus aureus, Escherichia coli and Pseudomonas aeruginosa were isolated from pharmaceutical effluent (Lateef, 2004).Water that entered into the distribution system has low heterotrophic plate counts (Florjanič and Kristl, 2006). Stenotrophomonas maltophilia was the most commonly isolated bacteria in samples taken from water supplies (Penna et al., 2002).

Identification was made for gramnegative non-fermenting bacteria, which were isolated from drinking water and water purification systems, since Pseudomonas genera represents opportunistic pathogens which disperse and adhere easily to surfaces, forming a biofilm which interferes with the cleaning and disinfection procedures in industrial environments. Seventy eight isolated colonies were identified as the following bacteria genera: Pseudomonas, Flavobacterium and Acinetobacter. According to the miniature kits used in the identification, there was a prevalence of isolation of $P$. aeruginosa $32.05 \%, P$. picketti (Ralstonia picketti) $23.08 \%, P$. vesiculares $12.82 \%$, P. diminuta $11.54 \%$, $F$. aureum $6.42 \%$, $P$. fluorescens $5.13 \%$, A. Iwoffi $2.56 \%$, P. putida $2.56 \%, P$. alcaligenes $1.28 \%, \quad P$. paucimobilis $1.28 \%$ and F. multivorum 1.28\% (Penna et al., 2002).

This study shows the importance of properly designed sampling technique, identification tools and careful intepretation and analysis of the results obtained in order to discover sources of contaminations in controlled environment to make immediate actions to prevent spreading of contaminant which may finally influence the microbiological quality of the final products which may lead to sever financial losses for pharmaceutical company. This study provides a new approach for detecting source of fault in controlled environment using trend and type of microorganisms. 


\section{MATERIALS AND METHODS Sampling locations:}

Samples were taken from representative different classes and locations in pharmaceutical facility including:

1- Facility water system: City water and purified water were obtained from water treatment and distribution system.

2- Class A1 (the highest grade of cleanliness): Microbiology laboratory laminar air flow units.

3- Class A2 (the highest grade of cleanliness): Sterility test isolator.

4-Class B (high grade of cleanliness):

Safety cabinet, sampling and dispensing laminar air flow units.

5-Class C (intermediate measure of cleanliness): Microbiology laboratory.

6-Class D1(low measure of cleanliness):

Ointment preparation and primary packaging, sampling room, dispensing room, oral liquid dosage form preparation and filling and suppositories preparation room.

7-Class D2 (low measure of cleanliness): Mixer and granulator room, drying oven room, tablet compression rooms, coating rooms, kneader room, capsule filling rooms, blistering lines I, II and primary tablet and capsule packaging rooms.

8-Class E (the least stringent cleanliness measures): Secondary capsules and tablets packaging, liquid formulation air lock, ointment primary packaging and suppositories air lock, blister lines corridor, ointment preparation air lock, powder preparation air lock, production entrance corridor, main material corridor and washing room air lock.

\section{Specimen collection:}

Water sampling (USEPA, $2002 \&$ Bordner et al., 1978):

1-The whole process of water sampling was performed under strict aseptic conditions. Water samples were collected in sterile polypropylene sample containers with leak proof lids. When collecting the sample, enough air space was left in the bottle to allow for proper mixing before examination. Samples representative of the water being tested were collected. Sample ports were flushed and disinfected and aseptic techniques were used to avoid sample contamination. The sample bottle was kept closed until it had to be filled. Cap was removed carefully to avoid contaminating the inner surface of the cap and neck of the bottle. Container was filled without rinsing. Cap was replaced immediately. The volume of sample should be sufficient to carry out all tests required (not less than $100 \mathrm{ml}$ ) (ASTM, 1993).

2-Residual chlorine in city water (or chlorinated effluent) samples were neutralized with sodium thiosulfate $(1 \mathrm{ml}$ of a $10 \%$ solution per liter of water) at the time of collection.

3-Water samples were kept at a temperature of $1-4^{\circ} \mathrm{C}$ during transit to the laboratory except when transportation time is very short.

4-Using a flamed forceps, a membrane filter (pore size $0.45 \mu \mathrm{m}$ ) was placed, with gridded-side up, on the porous plate of the filter base.

5-The funnel was attached to the base of the filtration unit. This allowed the membrane filter to be located between the funnel and the base.

6-Approximately $30 \mathrm{ml}$ of sterile phosphate-buffered solution water was poured in the bottom of the funnel.

7-The sample container was shaken vigorously 25 times. An appropriate volume (100 $\mathrm{ml}$ for water) was measured in graduated cylinder, and poured it into the funnel. The vacuum was turned on, and leave it on while rinsing the funnel twice with about $30 \mathrm{ml}$ sterile dilution water.

8-The membrane filter was held at its edge with a flamed forceps, gently lift and place the filter grid-side up on the tryptone soya agar plate.

9-The agar petridish was incubated for five days at $30^{\circ} \mathrm{C}-35^{\circ} \mathrm{C}$. 
Active air sampling (Pitt and Hocking, 1999):

1-Air sampler was placed in the center of each room at a height of approximately 1 meter above the floor.

2-The sampler was disinfected with 70\% ethanol before use at each location.

3-One thousand liters of air sampling were obtained by Reuter centrifugal sampler.

4-The agar strips TCI- $\gamma$ were incubated for 48 hours at $30^{\circ} \mathrm{C}-35^{\circ} \mathrm{C}$ and then for 72 hours at $20^{\circ} \mathrm{C}-25^{\circ} \mathrm{C}$.

5-After incubation, the colonies were counted and recorded in specific protocols.

Passive air sampling (Pasquarella et al., 2000):

1-Passive air sampling was performed by exposing two 9 centimeters Petri dishes containing tryptone soya agar medium to the air according to the $1 / 1 / 1$ scheme (for one hour, at a height of one meter at least one meter from walls or any obstacle) for each round and sampling room in areas where there was little air movement (i.e. "dead spaces") and where airflows converge were excessively turbulent and areas within the clean room where there was personnel activity or where specific operations were carried out.

2-All Petridishes were covered with the lid right after sampling, sealed with parafilm and incubated for 48 hours at $30^{\circ} \mathrm{C}-35^{\circ} \mathrm{C}$ and then for 72 hours at $20^{\circ} \mathrm{C}-25^{\circ} \mathrm{C}$.

\section{Surface monitoring:}

I- Contact plate method (Kastango and Douglass, 2001):

1-Surface sampling was performed with raised RODAC plates. The tryptone soya agar in contact plates was mixed with polysorbate 80 and lecithin, which inactivate many residual disinfectants. Polysorbate 80 neutralizes phenols, hexachlorophene, and formalin, and lecithin inactivates quaternary ammonium compounds.
2-During sampling, a contact plate was pressed onto the area to be tested. Any microorganisms on the surface of the area tested (which should ideally be flat) were transferred onto the contact plate.

3-After the sample had been obtained; the area tested had been wiped down with isopropyl alcohol $70 \%$ to remove any residue left by the contact plate.

4-The contact Plates were placed upside down in the incubator for 48 hours at $30^{\circ} \mathrm{C}-35^{\circ} \mathrm{C}$ and then for 72 hours at $20^{\circ} \mathrm{C}-25^{\circ} \mathrm{C}$.

II-Swabbing method (Sanderson et al., 2002):

1-Swab samples were collected by removing a sterile swab from a sterile tube, moistening it by inserting it into a second tube which contained a sponge soaked with sterile $1.5 \mathrm{ml}$ of phosphatebuffered saline (PBS) at $\mathrm{pH}$ 7.2.

2- The selected surface was swabbed by moving the swab back and forth across the surface with several horizontal strokes, then several vertical strokes. The swab was rotated during sampling to ensure that the entire surface of the swab was used.

3-After sampling, the swab was returned to its prelabeled sampling tube containing appropriate amount of liquid media.

Identification using miniaturized biochemical systems:

BBL CRYSTAL identification systems: Principle:

The tests used in the BBL CRYSTAL E/NF identification system are based on microbial utilization and degradation of specific substrates detected by various indicator systems. Gram-positive ID kit includes tests for fermentation, oxidation, degradation and hydrolysis of various substrates. In addition, there are chromogen and fluorogen linked substrates to detect enzymes that microbes use to metabolize various substrates (Hartman, 1968; Maddocks and Greenan, 1975; Killian and Bulow, 1976; Edberg and Kontnick, 1986; 
Manafi et al., 1991; Moncia et al., 1991 \& Mangels et al., 1993). Enzymatic hydrolysis of fluorogenic substrates containing coumarin derivatives, results in increased fluorescence that is easily detected visually with a UV light source (Maddocks and Greenan, 1975; Manafi et al., 1991 \& Moncia et al., 1991). Chromogenic substrates upon hydrolysis produce color changes that can be detected visually.

Identification is derived from a comparative analysis of the reaction pattern of the test isolate to those held in the data base (Murray et al., 1995).

\section{Procedure:}

Prior to BBL CRYSTAL E/NF panel set-up, oxidase and indole tests should be performed from a nonselective isolation plate no more than 24 hours old. The following steps were followed for microorganisms inoculation in the kit for both BBL CRYSTAL E/NF and BBL Crystal GP ID system:

1. Lids were removed from pouch. Desiccants were discarded. Once removed from the pouch, covered lids should be used within 1 hour.

2. An inoculum tubes were taken and labelled with specimens data and numbers. Using aseptic technique, with the tip of a sterile cotton swab or a wooden applicator stick or disposable plastic loop, well isolated large colonies were picked from a blood plate and suspended in a tube of BBL CRYSTAL Enteric/non fermenter or Gram positive inoculum fluid.

3. Tubes were recaped and vortexed for approximately 10-15 seconds. The turbidity should be equivalent to a McFarland standard no. 0.5.

4. Entire contents of inoculum fluids were poured into target area of base.

5. Bases were held in both hands and inocula were rolled gently along the tracks until all of the wells were filled.

6. The lids were aligned so that the labeled end of the lid is on top of the target area of the base.
7. The lids were pushed down until a slight resistance was felt.

8. Using a sterile loop, a small drop from the inoculum fluid tubes were recovered either before or after inoculating the base and an agar slants or plates (any appropriate media) were inoculated for purity check. The slants or plates were incubated for $18-24$ hours at $35-37^{\circ} \mathrm{C}$.

9. Inoculated panels were placed in incubation trays. Ten panels can fit in one tray (5 rows of 2 panels). All panels should be incubated face down with 40$60 \%$ humidity. The incubation time for panels is $18-20$ hours at $35-37^{\circ} \mathrm{C}$.

10. All panels should be read using the BBL CRYSTAL light box or panel viewer.

11. The resulting profile number and offline test results (indole and oxidase) should be entered on a PC in which the BBL CRYSTAL ID System Electronic Codebook has been installed, to obtain the identification.

\section{Identification of the yeast isolates} using API 20 C AUX (Schuffenecker et al., 1993):

Preparation of the strip:

- The incubation boxes (trays and lids) were prepared and about 5 $\mathrm{ml}$ of distilled water were distributed into the honeycombed wells of the tray to create a humid atmosphere.

- The isolate reference was recorded on the elongated flap of the tray.

- The strips were removed from its individual packaging and placed it in the incubation tray.

\section{Preparation of the inoculums:}

- Ampules of suspension medium were opened.

- Using a pipette, a portion of a yeast colonies were picked up by suction and a suspensions were made with a turbidity equal to McFarland standard no. 2.

- A single drops from each yeast isolates were dispensed onto the corn meal agar tween. 
- Ampules of $\mathrm{C}$ Medium (Ammonium sulphate $5 \mathrm{~g} / \mathrm{L}, \quad$ Monopotassium phosphate $0.31 \mathrm{~g} / \mathrm{L}, \quad$ Dipotassium phosphate $0.45 \mathrm{~g} / \mathrm{L}$, Disodium phosphate $0.92 \mathrm{~g} / \mathrm{L}$, Sodium chloride $0.1 \mathrm{~g} / \mathrm{L}$, Calcium chloride $0.05 \mathrm{~g} / \mathrm{L}$, Magnesium sulphate $0.2 \mathrm{~g} / \mathrm{L}$, Histidine $0.005 \mathrm{~g} / \mathrm{L}$, Tryptophane $0.02 \mathrm{~g} / \mathrm{L}$, Methionine 0.02 $\mathrm{g} / \mathrm{L}$, Agar-agar $0.5 \mathrm{~g} / \mathrm{L}$ ) were opened and $100 \mu \mathrm{l}$ (2-4 drops) of the previous suspensions were transferred into it. Gentle homogenization with pipettes was made and introduction of air bubbles were avoided.

\section{Inoculation of the strip:}

- The cupules of the strips were filled with the suspension obtained in the ampule of $\mathrm{C}$ Medium.

- The lids were placed on the tray and incubate at $30^{\circ} \mathrm{C}$ for $48-72$ hours.

Reading the strip:

After 48 or 72 hours of incubation if the tests, in particular glucose, were not clearcut after 48 hours, a check for growth (the 0 cupule serves as a negative control). A cupule more turbid than the control indicates a positive reaction to be recorded on the result sheet.

\section{Identification:}

Identification can be obtained:

Using the analytical profile index: the pattern of the reactions obtained must be coded into a numerical profile. On the result sheet, the tests are separated into groups of 3 and a number 1,2 or 4 is indicated for each. By adding the numbers corresponding to positive reactions within each group, a sevendigit number was obtained which constitutes the numerical profile. The presence of hyphae (mycelium) or pseudohyphae (pseudomycelium) constitutes the 21 st test and has a value of 4 when positive. Using the identification software by manually entering the 7-digit numerical profile via the keyboard.

\section{RESULTS}

Results of environmental monitoring samples taken from different locations in pharmaceutical facility:

Water sampling: City water samples were taken from water station while purified water samples were taken from different use points in production facility and quality control laboratory (chemistry, microbiology and washing rooms). Results were shown in Table (1). The total numbers of city water samples were 216 samples among which 62 samples (28.7\%) showed positive growth while 154 samples $(71.3 \%)$ showed no growth. The total numbers of purified water samples were 984 samples among which 130 samples (13.2\%) showed positive growth while 854 samples (86.8\%) showed no growth. City water showed greater number of positive samples in comparison with purified water.

Table 1: Water analysis of water plant samples taken from different use points.

\begin{tabular}{|c|c|c|c|c|c|c|c|}
\hline \multirow[t]{2}{*}{$\begin{array}{l}\text { Type of } \\
\text { samples }\end{array}$} & \multirow[t]{2}{*}{$\begin{array}{l}\text { Specified } \\
\text { limit }\end{array}$} & \multirow[t]{2}{*}{$\begin{array}{l}\text { Sampling } \\
\text { frequency }\end{array}$} & \multirow[t]{2}{*}{$\begin{array}{l}\text { Total no. } \\
\text { of samples }\end{array}$} & \multicolumn{2}{|c|}{$\begin{array}{l}\text { Positive } \\
\text { samples } \\
\end{array}$} & \multicolumn{2}{|c|}{$\begin{array}{c}\text { Negative } \\
\text { samples } \\
\end{array}$} \\
\hline & & & & No. & $\%$ & No. & $\%$ \\
\hline City water & $<50.000 \mathrm{CFU} / 100 \mathrm{ml}$ & once/month & 216 & 62 & 28.7 & 154 & 71.3 \\
\hline Purified water & $<10.000 \mathrm{CFU} / 100 \mathrm{ml}$ & once/week & 984 & 130 & 13.2 & 854 & 86.8 \\
\hline
\end{tabular}

Surface monitoring: All samples were taken using contact plates from production area and microbiology laboratory in facility except sterility test isolator samples were taken by swab technique. Results were shown in Table (2). All samples of classes A1 (3456 samples), A2 (1008 samples), B1 (144 samples) and B2 (1728 samples) showed no growth. Out of 2496 samples of class C 1700 samples (68.1\%) showed positive growth and 796 samples (31.9\%) showed no growth. All samples of class D1 and D2 showed positive growth. 
Table 2: Surface monitoring in pharmaceutical facility using either swab technique or contact plate method.

\begin{tabular}{|c|c|c|c|c|c|c|c|}
\hline \multirow{2}{*}{ Classes } & \multirow{2}{*}{$\begin{array}{l}\text { Specified } \\
\text { limit }\end{array}$} & \multirow{2}{*}{$\begin{array}{l}\text { Sampling } \\
\text { frequency }\end{array}$} & \multirow{2}{*}{$\begin{array}{l}\text { Total no. } \\
\text { of samples }\end{array}$} & \multicolumn{2}{|c|}{$\begin{array}{l}\text { Positive } \\
\text { samples }\end{array}$} & \multicolumn{2}{|c|}{$\begin{array}{c}\text { Negative } \\
\text { samples }\end{array}$} \\
\hline & & & & No. & $\%$ & No. & $\%$ \\
\hline Class A1 & $\begin{array}{c}<1 \mathrm{CFU} / \text { plate } \\
\text { (wall and benches) }\end{array}$ & Once/shift & 3456 & 0 & 0.0 & 3456 & 100.0 \\
\hline Class A2 & $<1 \mathrm{CFU} /$ swab & Once/shift & 1008 & 0 & 0.0 & 1008 & 100.0 \\
\hline Class B1 & $\begin{array}{l}<5 \mathrm{CFU} / \text { plate (wall) } \\
<10 \mathrm{CFU} / \text { plate (bench) }\end{array}$ & $\begin{array}{l}\text { Once/month } \\
\text { during activity }\end{array}$ & 144 & 0 & 0.0 & 144 & 100.0 \\
\hline Class B2 & $\begin{array}{l}<5 \mathrm{CFU} / \text { plate }(\text { wall }) \\
<10 \mathrm{CFU} / \text { plate }(\text { bench) }\end{array}$ & Once/shift & 1728 & 0 & 0.0 & 1728 & 100.0 \\
\hline Class C & $\begin{array}{l}<25 \mathrm{CFU} / \text { plate (wall) } \\
<50 \mathrm{CFU} / \text { plate (floor) }\end{array}$ & Twice/week & 2496 & 1700 & 68.1 & 796 & 31.9 \\
\hline Class D1 & $\begin{array}{l}<50 \mathrm{CFU} / \text { plate } \\
\text { (wall and floor) }\end{array}$ & $\begin{array}{l}\text { Once/month } \\
\text { during activity }\end{array}$ & 408 & 408 & 100.0 & 0 & 0.0 \\
\hline Class D2 & $\begin{array}{l}<50 \mathrm{CFU} / \text { plate } \\
\text { (wall and floor) }\end{array}$ & $\begin{array}{l}\text { Once } / 3 \text { months } \\
\text { during activity }\end{array}$ & 232 & 232 & 100.0 & 0 & 0.0 \\
\hline
\end{tabular}

Class A1: Microbiology laboratory laminar air flow units.

Class A2: Sterility test isolator.

Class B1: Sampling and dispensing LAF walls and benches.

Class B2: Safety cabinet.

Class C : Microbiology laboratory.

Class D1: Ointment preparation and primary packaging, sampling room, dispensing room, oral liquid dosage form preparation and filling and suppositories preparation room.

Class D2: Mixer and granulator room, drying oven room, tablet compression rooms, coating rooms I and II, kneader room, capsule filling rooms, blistering lines and primary tablet and capsule packaging rooms.

Viable passive air sampling: Samples were taken from microbiology laboratory and production area in facility using settle plate technique. Results were shown in table (3). All samples of class
A which was composed of 1152 samples showed no growth while all samples of class C (72 samples), class D1 (408 samples) and class D2 (160 samples) showed positive growth.

Table 3: Viable passive air monitoring using settle plate technique.

\begin{tabular}{|c|c|c|c|c|c|c|c|}
\hline \multirow{2}{*}{ Classes } & \multirow{2}{*}{$\begin{array}{l}\text { Specified } \\
\text { limit }\end{array}$} & \multirow{2}{*}{$\begin{array}{l}\text { Sampling } \\
\text { frequency }\end{array}$} & \multirow{2}{*}{$\begin{array}{l}\text { Total no. } \\
\text { of samples }\end{array}$} & \multicolumn{2}{|c|}{$\begin{array}{l}\text { Positive } \\
\text { samples }\end{array}$} & \multicolumn{2}{|c|}{$\begin{array}{l}\text { Negative } \\
\text { samples }\end{array}$} \\
\hline & & & & No. & $\%$ & No. & $\%$ \\
\hline Class A & $<1 \mathrm{CFU} / 2$ hour & Once/shift & 1152 & 0 & 0.0 & 1152 & 100.0 \\
\hline Class C & $<50 \mathrm{CFU} / 4$ hours & Once/month & 72 & 72 & 100.0 & \begin{tabular}{|l|l}
0 \\
\end{tabular} & 0.0 \\
\hline Class D1 & $<100 \mathrm{CFU} / 4$ hours & Once/month & 408 & 408 & 100.0 & 0 & 0.0 \\
\hline Class D2 & $<100 \mathrm{CFU} / 4$ hours & Once/3 months & 160 & 160 & 100.0 & 0 & 0.0 \\
\hline
\end{tabular}

Class A: Microbiology laboratory laminar air flow units.

Class C: Microbiology laboratory.

Class D: Ointment preparation and primary packaging, sampling room, dispensing room, oral liquid dosage form preparation and filling and suppositories preparation room.

Class D2: Mixer and granulator room, drying oven room, tablet compression rooms, coating rooms I and II, kneader room, capsule filling rooms, blistering lines and primary tablet and capsule packaging rooms. 
Viable active air sampling: Samples were taken from microbiology laboratory and production area in facility using air sampling apparatus (reuter centrifugal sampler) for quantitative determination of microorganisms. Results were shown in Table (4). All samples of class A1 (48 samples) and class A2 (144 samples) showed negative growth in contrast to all samples of class C (576 samples), class D1 (192 samples), class D2 (12 samples) and class $\mathrm{E}$ (80 samples) which showed positive growth. Thirty five samples (48.6\%) out of 72 samples of class B show positive growth while 37 samples (51.4\%) showed no growth.

Table 4: Viable active air monitoring using reuter centrifugal sampler (RCS) technique.

\begin{tabular}{|l|l|l|c|c|c|l|l|}
\hline \multirow{2}{*}{ Classes } & \multirow{2}{*}{$\begin{array}{l}\text { Specified } \\
\text { limit }\end{array}$} & \multirow{2}{*}{$\begin{array}{l}\text { Sampling } \\
\text { frequency }\end{array}$} & \multirow{2}{*}{$\begin{array}{l}\text { Total no. } \\
\text { of samples }\end{array}$} & \multicolumn{2}{|l|}{$\begin{array}{l}\text { Positive } \\
\text { samples }\end{array}$} & \multicolumn{2}{|l|}{$\begin{array}{l}\text { Negative } \\
\text { samples }\end{array}$} \\
\cline { 5 - 9 } & & & & No. & $\%$ & No. & $\%$ \\
\hline Class A1 & $<1 \mathrm{CFU} / \mathrm{m}^{3}$ & Once/month during activity & 48 & 0 & 0.0 & 48 & 100.0 \\
\hline Class A2 & $<1 \mathrm{CFU} / \mathrm{m}^{3}$ & Once/shift & 144 & 0 & 0.0 & 144 & 100.0 \\
\hline Class B & $<10 \mathrm{CFU} / \mathrm{m}^{3}$ & Once/month during activity & 72 & 35 & 48.6 & 37 & 51.4 \\
\hline Class C & $<100 \mathrm{CFU} / \mathrm{m}^{3}$ & Twice/week during activity & 576 & 576 & 100.0 & 0 & 0.0 \\
\hline Class D1 & $<200 \mathrm{CFU} / \mathrm{m}^{3}$ & Once/month during activity & 192 & 192 & 100.0 & 0 & 0.0 \\
\hline Class D2 & $<200 \mathrm{CFU} / \mathrm{m}^{3}$ & Once/3 months during activity & 12 & 12 & 100.0 & 0 & 0.0 \\
\hline Class E & $<500 \mathrm{CFU} / \mathrm{m}^{3}$ & Once $/ 3$ months & 80 & 80 & 100.0 & 0 & 0.0 \\
\hline
\end{tabular}

Class A1: Microbiology laboratory laminar air flow units.

Class A2: Sterility test isolator.

Class B: Safety cabinet, sampling and dispensing LAF units.

Class C: Microbiology laboratory.

Class D1: Ointment preparation and primary packaging, sampling room, dispensing room, oral liquid dosage form preparation and filling and suppositories preparation room.

Class D2: Mixer and granulator room, drying oven room, tablet compression rooms, coating rooms I and II, kneader room, capsule filling rooms, blistering lines and primary tablet and capsule packaging rooms.

Class E : Secondary capsules and tablets packaging, liquid formulation air lock, ointment primary packaging and suppositories air lock, blister lines corridor, ointment preparation air lock, powder preparation air lock, production entrance corridor, main material corridor and washing room air lock.

\section{Distribution of identified microorganisms from the positive samples of environmental monitoring specimens:}

Twenty one bacterial and fungal species were isolated from different locations in the pharmaceutical facility.

Group of genus Staphylococci contributes to $38.4 \%$ of total positive samples while genus Micrococci contributes to $22.4 \%$ and Gemella morbillorum represents $1.1 \%$. Genus
Bacilli represents $35.0 \%$, Candida albicans $1.3 \%$, Klebsiella pneumonia $1.0 \%$ and Stenotrophomonas maltophilia $0.01 \%$. Results were shown in Table (5).

The abundance of the environmental isolates was in the following descending order: genus Staphylococci, Genus Bacilli, genus Micrococci, Candida albicans, Klebsiella pneumonia and Stenotrophomonas maltophilia. 
Table 5: Distribution of microorganisms between different samples.

\begin{tabular}{|c|c|c|c|c|c|c|c|c|c|}
\hline \multirow{3}{*}{ Microrganisms } & \multicolumn{8}{|c|}{ Sample type } & \multirow{3}{*}{$\begin{array}{c}\text { Percentage of } \\
\text { organism from } \\
\text { total positive } \\
\text { samples }\end{array}$} \\
\hline & \multicolumn{2}{|r|}{ Water } & \multicolumn{2}{|c|}{ Contact plate } & \multicolumn{2}{|r|}{ Settle } & \multicolumn{2}{|r|}{ RCS* } & \\
\hline & $\begin{array}{l}\text { No. of } \\
\text { positive } \\
\text { samples }\end{array}$ & $\begin{array}{l}\text { Percentage from } \\
\text { total positive } \\
\text { samples }\end{array}$ & $\begin{array}{c}\text { No. of } \\
\text { positive } \\
\text { samples }\end{array}$ & $\begin{array}{c}\text { Percentage } \\
\text { from total } \\
\text { positive } \\
\text { samples } \\
\end{array}$ & $\begin{array}{c}\text { No. of } \\
\text { positive } \\
\text { samples }\end{array}$ & $\begin{array}{c}\text { Percentage from } \\
\text { total positive } \\
\text { samples }\end{array}$ & $\begin{array}{l}\text { No. of } \\
\text { positive } \\
\text { samples }\end{array}$ & $\begin{array}{l}\text { Percentage from } \\
\text { total positive } \\
\text { samples }\end{array}$ & \\
\hline $\begin{array}{c}\text { Staphylococcus } \\
\text { aureus }\end{array}$ & 0 & $0.0 \%$ & 64 & $2.752 \%$ & 0 & $0.0 \%$ & 0 & $0.0 \%$ & $1.226 \%$ \\
\hline $\begin{array}{c}\text { Staphylococcus } \\
\text { capitis }\end{array}$ & 0 & $0.0 \%$ & 164 & $7.009 \%$ & 328 & $18.303 \%$ & 50 & $5.587 \%$ & $10.38 \%$ \\
\hline $\begin{array}{c}\text { Staphylococcus } \\
\text { cohnii }\end{array}$ & 0 & $0.0 \%$ & 88 & $3.752 \%$ & 0 & $0.0 \%$ & 40 & $4.469 \%$ & $2.452 \%$ \\
\hline $\begin{array}{c}\text { Staphylococcus } \\
\text { epidermidis }\end{array}$ & 1 & $0.52 \%$ & 205 & $8.761 \%$ & 0 & $0.0 \%$ & 0 & $0.0 \%$ & $3.947 \%$ \\
\hline $\begin{array}{c}\text { Staphylococcus } \\
\text { haemolyticus }\end{array}$ & 1 & $0.52 \%$ & 163 & $7.008 \%$ & 530 & $29.575 \%$ & 53 & $5.922 \%$ & $14.313 \%$ \\
\hline $\begin{array}{c}\text { Staphylococcus } \\
\text { saprophyticus }\end{array}$ & 0 & $0.0 \%$ & 82 & $3.504 \%$ & 317 & $17.689 \%$ & 162 & $18.101 \%$ & $10.749 \%$ \\
\hline $\begin{array}{c}\text { Staphylococcus } \\
\text { schleiferi }\end{array}$ & 0 & $0.0 \%$ & 90 & $3.846 \%$ & 8 & $0.446 \%$ & 0 & $0.0 \%$ & $1.877 \%$ \\
\hline $\begin{array}{c}\text { Staphylococcus } \\
\text { simulans }\end{array}$ & 0 & $0.0 \%$ & 65 & $2.777 \%$ & 0 & $0.0 \%$ & 0 & $0.0 \%$ & $1.245 \%$ \\
\hline $\begin{array}{c}\text { Staphylococcus } \\
\text { vitulinus }\end{array}$ & 0 & $0.0 \%$ & 76 & $3.252 \%$ & 0 & $0.0 \%$ & 0 & $0.0 \%$ & $1.456 \%$ \\
\hline $\begin{array}{c}\text { Staphylococcus } \\
\text { warneri }\end{array}$ & 0 & $0.0 \%$ & 0 & $0.0 \%$ & 0 & $0.0 \%$ & 49 & $5.475 \%$ & $0.938 \%$ \\
\hline $\begin{array}{l}\text { Micrococcus } \\
\text { luteus }\end{array}$ & 0 & $0.0 \%$ & 208 & $8.888 \%$ & 356 & $19.866 \%$ & 303 & $33.855 \%$ & $16.612 \%$ \\
\hline $\begin{array}{c}\text { Micrococcus } \\
\text { lylae }\end{array}$ & 0 & $0.0 \%$ & 86 & $3.675 \%$ & 191 & $10.658 \%$ & 179 & $20 \%$ & $8.737 \%$ \\
\hline $\begin{array}{l}\text { Candida } \\
\text { albicans }\end{array}$ & 0 & $0.0 \%$ & 58 & $2.478 \%$ & 0 & $0.0 \%$ & 10 & $1.117 \%$ & $1.302 \%$ \\
\hline $\begin{array}{c}\text { Klebsiella } \\
\text { pneumonia }\end{array}$ & 0 & $0.0 \%$ & 64 & $2.752 \%$ & 0 & $0.0 \%$ & 0 & $0.0 \%$ & $1.226 \%$ \\
\hline $\begin{array}{c}\text { Stenotrophomond } \\
\text { maltophilia }\end{array}$ & 12 & $6.25 \%$ & 0 & $0.0 \%$ & 0 & $0.0 \%$ & 0 & $0.0 \%$ & $0.229 \%$ \\
\hline $\begin{array}{c}\text { Gemella } \\
\text { morbillorum }\end{array}$ & 0 & $0.0 \%$ & 0 & $0.0 \%$ & 0 & $0.0 \%$ & 43 & $4.804 \%$ & $0.823 \%$ \\
\hline $\begin{array}{l}\text { Bacillus } \\
\text { cereus }\end{array}$ & 158 & $82.291 \%$ & 94 & $4.017 \%$ & 18 & $1.004 \%$ & 6 & $0.007 \%$ & $5.288 \%$ \\
\hline $\begin{array}{l}\text { Bacillus } \\
\text { circulans }\end{array}$ & 0 & $0.0 \%$ & 96 & $4.12 \%$ & 0 & $0.0 \%$ & 0 & $0.0 \%$ & $1.839 \%$ \\
\hline $\begin{array}{c}\text { Bacillus } \\
\text { licheniformis }\end{array}$ & 14 & $7.291 \%$ & 123 & $5.256 \%$ & 0 & $0.0 \%$ & 0 & $0.0 \%$ & $2.625 \%$ \\
\hline $\begin{array}{l}\text { Bacillus } \\
\text { pumilus }\end{array}$ & 6 & $3.125 \%$ & 327 & $14.017 \%$ & 0 & $0.0 \%$ & 0 & $0.0 \%$ & $6.380 \%$ \\
\hline $\begin{array}{l}\text { Bacillus } \\
\text { subtilis }\end{array}$ & 0 & $0.0 \%$ & 287 & $12.265 \%$ & 44 & $2.455 \%$ & 0 & $0.0 \%$ & $6.342 \%$ \\
\hline
\end{tabular}

*: Reuter centrifugal sampler.

\section{DISCUSSION}

City water showed higher proportion of positive samples if compared with purified water although it contains chlorine yet purified water disinfection by ozone was more efficient in bioburden control of water and this factor may be one of the major reasons 
account for lower proportion of negative samples for purified water if compared to city water. The results were in agreement with that of Florjanič and Kristl (2006) who found that the purified water that entered into the distribution system has low heterotrophic plate counts. Purified water storage and distribution systems at ambient temperature are highly susceptible to microbial contamination and formation of biofilm but the specified ozone level prevented microbial growth and formation of biofilm in the distribution system that might otherwise endanger the water quality by sporadic release of microbes.

In the environmental monitoring results Staphylococcus species were the predominant microorganism isolated (38.4\% from total positive samples) followed by Bacillus species (25.8\% from total positive samples) then Micrococcus species (22.4\%). Although the results showed that Staphylococcus and Micrococcus species were very sensitive microorganism compared to others in this study yet they were very common in the environmental samples especially reuter centrifugal sampler (RCS), contact plate samples by replicate organism detection and counting (RODAC) method and settle plates. Staphylococcus and Micrococcus species were common isolates of different air samples were effect of disinfectants were nil and most of these microorganisms are human flora which comes from operators in these area. Mancinelli and Shulls (1978) found that the most frequently isolated organisms were Micrococcus (41\%), Staphylococcus (11\%), and Aerococcus (8\%) in urban air and Micrococcus was frequently found in air sampling because it produces pigments that protect it against the radiation of sunshine. During the collection of airborne bacteria in a museum in England some bacterial strains were isolated which due to their fatty acid profiles were clearly identified as members of the genus Staphylococcus (Wieser and Busse, 2000).

One species belonging to Staphylococcus group (Staphylococcus haemolyticus) was found in water. This result was in agreement with that obtained from the study of Lateef (2004).

On the other hand Bacillus species were widely distributed among different types of samples but their occurrence in air samples was minimum. Being spore forming microorganisms, Bacillus species were able to survive different unfavorable environmental conditions and this may explain their distribution among all samples and this can be explained by endospore formation, a property universally found in the Bacillus group, is thought to be a strategy for survival in the soil environment, where in these bacteria predominate. Aerial distribution of the dormant spores probably explains the occurrence of aerobic spore formers in most habitats examined (Todar, 2009).

Candida albicans were found in air and surfaces. Klebsiella pneumonia was found in surface samples. Gemella morbillorum was found in air samples only. Kramer et al. (2006) found that Candida albicans as the most important nosocomial fungal pathogen can survive up to 4 months on surfaces and they reported also that many gram-negative species, such as Acinetobacter species, Escherichia coli, Klebsiella species, Pseudomonas aeruginosa, Serratia marcescens, and Shigella species, can also survive for months.

Stenotrophomonas maltophilia was found in water samples. Penna et al. (2002) found that the most commonly isolated bacteria were Stenotrophomonas maltophilia in samples taken from water supplies. This result was in agreement with that of Lateef (2004) who found Pseudomonas species in the effluent of a pharmaceutical company. 


\section{REFERENCES}

ASTM (1993) Standard Specification for Reagent Water, Designation D119391, In: Annual Book of ASTM Standards. American Society for Testing and Materials, Philadelphia, $P A$. Water and Environmental Technology. Volume 11(1): 45-47.

Bordner, R., Winter, J. and Scarpino, P. (ed). (1978) Microbiological Methods for Monitoring the Environment: Water and Wastes. EPA-600/8-78-017, Environmental Monitoring and Support Laboratory, U.S. Environmental Protection Agency, Cincinnati, $\mathrm{OH}$.

CDER (2003) Guidance for Industry Sterile Drug Products Produced by Aseptic Processing-Current Good Manufacturing Practice. Draft Guidance, 1-59.

Edberg, S. C. and Kontnick, C.M. (1986) Comparison of $\beta$ glucuronidase-based substrate systems for identification of Escherichia coli. J. Clin. Microbiol., 24:368-371.

FDA (2002) Sterile Drug Products Produced by Aseptic Processing Draft. Preliminary Concept Paper, 146.

Florjanic, M. and Kristl, J. (2006) Microbiological quality assurance of purified water by ozonization of storage and distribution system. Drug Develop Industr Pharm 32(10), 1113-1112.

Hartman, P.A. (1968) Miniaturized microbiological methods. Academic Press, New York. Kampfer, P.; Rauhoff, O. and Dott, W. Glycosidase profiles of members of the family Enterobacteriaceae. J. Clin. Microbiol., 29:2877-2879.

Jiminez, L. (2004) Microorganisms in the Environment and their relevance to Pharmaceutical Processes. In: Microbial Contamination Control in the Pharmaceutical Industry, ed. Jiminez, L. and Marcel-Dekker, pp 8-9. New York.
Kastango, E.S. and Douglass, K. (2001) Quality Assurance for Sterile Products. Intl $J$ Pharmaceut Compound 5(4),246-253.

Killian, M. and Bulow, P. (1976) Rapid diagnosis of Enterobacteriaceae 1: detection of bacterial glycosidases. Acta Pathol. Microbiol. Scand. Sect. B., 84:245-251.

Kramer, A., Schwebke, I. and Kampf, G. (2006) How long do nosocomial pathogens persist on inanimate surfaces? A systematic review. BMC Infectious Diseases 6,130-137.

Lateef, A. (2004) The microbiology of a pharmaceutical effluent and its public health implications. World $J$ Microbiol Biotechnol 20(2):167-171.

Maddocks, J.L. and Greenan, M. (1975) Rapid method for identifying bacterial enzymes. J. Clin. Pathol., 28:686-687.

Manafi, M.; Kneifel, W. and Bascomb, S. (1991) Fluorogenic and chromogenic substrates used in bacterial diagnostics. Microbiol. Rev., 55:335-348.

Mancinelli, R.L. and Shulls, W.A. (1978) Airborne Bacteria in an Urban Environment. Appl Environ Microbiol 35(6),1095-1101.

Mangels, J., Edvalson, I. and Cox, M. (1993) Rapid Identification of Bacteroides fragilis group organisms with the use of 4methylumbelliferone derivative substrates. Clin. Infect. Dis., 16(54):5319-5321.

Mashburn, J.C. and Whitfield, W.J. (1967): The development of a faster monitoring system. Contam Control., 6(12):10-11.

Moncia, B.J., Braham, P., Rabe, L.K. and Hiller, S.L. (1991) Rapid presumptive identification of blackpigmented gram-negative anaerobic bacteria by using 4methylumbelliferone derivatives. J. Clin. Microbiol., 29: 1955-1958.

Murray, P.R., Baron, E.J., Pfaller, M.A., 
Tenover, F.C. and Yolken, R.H. (1995) Manual of Clinical Microbiology, 6th ed. American Society for Microbiology, Washington, D. C.

Pasquarella, C., Pitzurra, O. and Savino, A. (2000): The index of microbial air contamination. $J$ Hosp Infec 46(4), 241-256.

Penna, V.T.C., Martins, S.A.M. and Mazzola, P.G. (2002) Identification of bacteria in drinking and purified water during the monitoring of a typical water purification system. BMC Public Health 2,13-23.

Pitt, J.I. and Hocking, A.D. (1999): Fungi and food spoilage. Maryland: Aspen publisher.

Sanderson, W.T., Hein, M.J., Taylor, L., Curwin, B.D., Kinnes, G.M., Seitz, T.A., Popovic,T., Holmes, H.T., Kellum, M.E., McAllister, S.K., Whaley, D.N., Tupin, E.A., Walker, T., Freed, J.A., Small, D.S., Klusaritz, B. and Bridges, J.H. (2002) Surface Sampling Methods for Bacillus anthracis Spore Contamination. Emerging Infectious Diseases 8(10), 1145-1151.

Sandle, T. (2006) Environmental Monitoring Risk Assessment. Journal of GXP Compliance, 10(2):231-237.

Schuffenecker, I., Freydiere, A., De Montclos, H. and Gille, Y. (1993)
Evaluation of Four Commercial Systems for Identification of Medically Important Yeasts. Eur. J. Clin. Microbiol. Infect. Dis., 12:255260.

Todar, K. (2009) Introduction: Bacillus anthracis and Anthrax (p.1) [cited at www.textbookofbacteriology.net].

USEPA (2002): Total Coliforms and Escherichia coli in Water by Membrane Filtration Using a Simultaneous Detection Technique (MI Medium). Method 1604: p. 1-14. USP (2001) United States Pharmacopea and national formulary $<1116>$ microbiological evaluation of clean rooms and other controlled environments Vol. 31, No. 2, Page 524.

Wieser, M. and Busse, H. (2000) Rapid identification of Staphylococcus epidermidis. Int $J$ System Evolut Microbiol 50, 1087-1093.

York, M.K., Traylor, M.M., Hardy, J. and Henry, M. (2004) Biochemical tests for the identification of aerobic bacteria, In: H.D. Isenberg (ed.), Clinical microbiology procedures handbook 2nd ed., vol. 1, 2 and 3. American Society for Microbiology, Washington, D.C. p. 3.17-39.1.

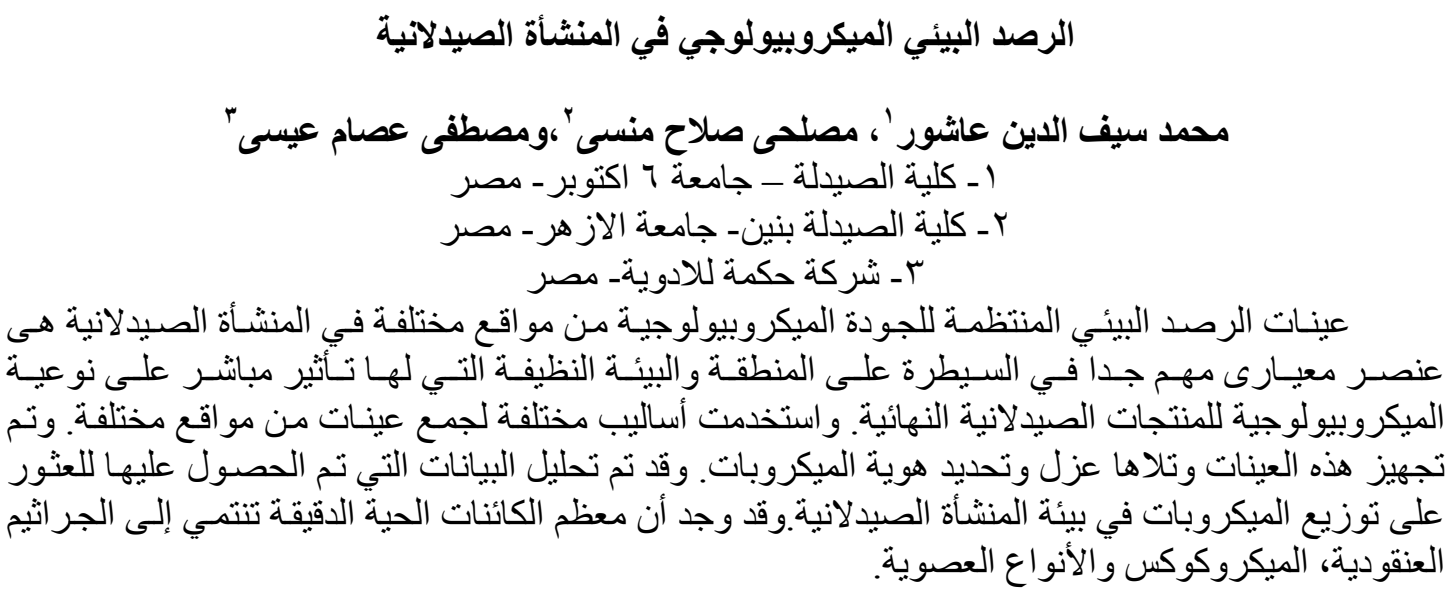

